\title{
Financial covenants and financial reporting conservatism: French evidence
}

\author{
Miss Raja Hached Ismail \\ Department of Accounting, Faculté des sciences économiques et de gestion, Sfax University, Tunisia \\ E-mail: hachedraja@yahoo.fr
}

Copyright $\odot 2014$ Raja Hached Ismail. This is an open access article distributed under the Creative Commons Attribution License, which permits unrestricted use, distribution, and reproduction in any medium, provided the original work is properly cited.

\begin{abstract}
We examine the relation between the use of financial covenants in private debt contract and financial reporting conservatism for a sample of French firms. More specifically, we seek to know if the existence of financial covenants on private debt contracts leads managers to exhibit more timely loss recognition. Using a sample of 488 French firms operating in various sector during the period going from 2003 to 2009, we found that the reliance on financial covenants in private lending agreements is positively associated with the demand of timely loss recognition.
\end{abstract}

Keywords: Accouting Conservatism, Agency Problems, Accounting Quality. Financial Covenants, Private Debt Contracts.

\section{Introduction}

Financial covenants requirements arise from agency problems in financial relationships. The literature explains financial covenants as a signaling device to address ex ante information difference between borrowers and lenders. In particular, financial covenants are also designed to limit debtholders wealth expropriation when a firm approaches financial distress. These models predict that financial covenants incite borrowers to show their type. Another set of research shows that the use of financial covenants is like a part of an optimal debt contract. These financial covenants were identified for the first time by Smith and Warner [1], are expressed as accounting ratios not to exceed at the risk of cause debt renegotiation or make it immediately due. Nevertheless, as financial covenants normally become irrevocable when accounting performance decline under a certain limit, they protect debtholders simply to the degree that a manager's discretion to delay the recognition of bad news in earnings is limited. The literature identifies that accounting information is beneficial in contracting and that the demands of contracting parties create its properties as mentioned by Watts and Zimmerman [2]. Exactly, debt contracting shapes demand for conservatism as described by Watts [3]. Although, there is a large body of research on financial covenants use in debt contracts, the majority of research focuses on the Anglo Saxon context. As a result, it will be very interesting to know about financial covenants in French context. A question that arises is whether there are other mechanisms that lender can use to improve efficiency in setting financial covenants requirements. In this research, we focus on borrowers' financial reporting conservatism and study how it relates to the use of financial covenants in addressing the debt agency problem in French firms.

The conservatism interpreted by Basu [4] as "the accountant's tendency to require a higher degree of verification to recognize good news as gains than to recognize bad news as losses". Four explanations for conservatism are advanced by Watts [3]: contracting, litigation regulation and taxation. Under contracting explanation, conservatism is a tool of addressing moral hazard. In the context of risky debt financing, many problems can arise such as underinvestment, asset substitution and overinvestment that lead the lenders to demand timely information about the value of the firm's net assets in the case of liquidation. The implications of these problems are of serious concern to lenders when the value of the firm falls and the incentives of managers to postpone the recognition of bad news afraid of losing control rights. Many financial covenants such as interest coverage ratio, restrain managers from expropriating the wealth of lenders when firms approaches financial distress. Covenants that limit such problems become binding only if the financial reporting system recognizes the falling value of the firm. As a result, financial reporting conservatism can improve the efficiency of these covenants because they are more likely to be binding in distress and to restrain wealth expropriation 
by managers. By the way, the use of financial covenants on debt contracts lead to increased demand for conservatism. Both lenders and borrowers benefit from conservatism as mentioned by Zhang [5]. The majority of studies examining the contracting explanation focus on conditional conservatism [5-7], referred to as news dependent, which involves firms writing down the book value of net assets in a timely manner upon receiving bad news but not writing up net assets in a timely manner upon receiving good news. In contrast, unconditional conservatism generally referred to as news independent, which implies the predetermined underestimation of the book value of net assets. Under unconditional conservatism, firms commit at inception to recognizing book values of net assets that are below the expected market values during their lives as described by Ryan [8]. The conditional conservatism increase contracting efficiency rather than unconditional conservatism as indicated by Ball [9]. Consequent the prior literature, we focus our attention on the role of conditional conservatism in private debt contract, and more exactly on the relation between the use of financial covenants on private debt contracts and the degree of conservatism in annual reports like Guay and Verrecchia [10]. As a result, we measure timely loss recognition following the model of Basu [4]. More conservative borrowers are more likely to violate debt covenants and to violate them sooner, so conservatism benefits lenders at the expense of borrowers as indicated by Zhang [5]. It's reasonable to argue that lenders are willing to share the benefits with conservative borrowers in the form of reduced or increased use of financial covenants.

The literature leant at first on the impact of debt on accounting conservatism. In fact, as expressed by Watts [3] that the practice of accounting conservatism can be explained by debt contracts. This author asserted that the accounting conservatism play an important role in the attenuation of interest conflicts between debtholders and managers. The accounting conservatism helps to reduce the cost of debt through a more reduced interest rate as shown by WittenbergMoreman [12]. The literature was secondly interested to the impact of financial covenants on accounting conservatism. Few works has been focused on how the degree of timely loss recognition is related to financial covenants of private debt contracts and the results are mixed. First, the ex-ante conservatism can be negatively associated with financial and general covenants in private debt contracts $[13,16]$. Second, the conservatism can increase with the number of financial covenants inherent in public debt contract as shown by Nikolaev [6]. Finally, there's no association between these two mechanisms $[14,15]$. In this paper, we focus our interest on the role of timely loss recognition in debt contract and more specifically on the direct link between financial covenants and the degree of accounting conservatism in the French context. We hand collect information on the use of financial covenants and earnings and return stock disclosed in firms' annual reports for 488 firm-year observations between 2003 and 2009. Following Basu [4], we measure the timely loss recognition via a linear regression of earnings on positive stock return (as a proxy of good news) and on negative stock return (as a proxy of bad news). We first document that firms with financial covenants in their private debt are timely in their economic loss recognition. Next, we add some control variables that are likely to affect the degree of conservatism such as leverage, market to book ratio, size and the adoption of IAS/IFRS; we find no effect of these control variables on accounting conservatism.

This study has two outstanding contributions to the literature. The first contribution of this study; we extend the conservatism literature by directly testing the relation between the use of financial covenants and conservatism. Our study shows that the use of financial covenants can be a complement to accounting conservatism in reducing interest conflicts between debtholders and managers. Our study also makes another contribution to the conservatism literature. The adoption of IAS/IFRS has no effect on the degree of accounting conservatism in French context.

The next section reviews the related literature and describes the empirical predictions. Section 3 develops the methodology and model. We present in section 4 the findings and discuss the results of our main tests and present our conclusions in the last section.

\section{Literature review}

Financial covenants are provisions that require the borrower to maintain a minimum level of a financial ratio, for example, interest coverage, net worth. Covenants requirements are widely used in private or public loan contracts to address agency problems between borrowers and lenders and to limit the ability of manager to expropriate lenders wealth through many actions. These actions can be under the form of asset substitution, claim dilution and over and underinvestment [17], [18]. Although, covenants can reduce these types of agency problems but they can reduce the manager ability to take decisions that are beneficial to the firm in financial distress. The trade-off between the costs and the benefits of covenants consequently plays a role in the design of debt contracts as mentioned by Begley [19].

Conservatism represents a dimension of accounting quality and plays an important role in enhancing the contracting efficiency. By recognizing losses in a timely manner in earnings contribute to covenant violations in the case of distressed firms. Financial covenants are often based on accounting information that is directly related to reported earnings and balance sheet. Financial covenants with accounting numbers that incorporate timely losses in earnings are more effective to limit the agency problems of debt and to make sure the early transfer of decision rights from managers to debtholders when a firm approaches financial distress. As a result, debt contracts with financial covenants based on accounting information and timely loss recognition enhance the contracting efficiency. Consistent with this idea, debt contracts with financial covenants exhibit more timely loss recognition consequently financial covenants and conservatism are two complements mechanisms as shown by Nikolaev [6] and an optimal contracting mechanism as 
mentioned by Levine et Hughes [20]. To the extent of this complementary view, the inclusion of financial covenants on debt contracts should be related with a higher demand for conservatism.

Fewer studies have examined the impact of financial covenants on accounting quality. Certain researchers wanted to study the link between financial covenants presence and the degree of accounting conservatism. For that purpose, Hong et al. [21] examine the use of debt covenants all over the world, their institutional determinants and their consequences on timely loss recognition. To test their hypotheses, they use a sample of 7,053 firm-year observations with syndicated debt (49,122 firm-years) from 23 countries over the period 1990 to 2009. The authors focus on bank debt contracts because covenants on this type of debt are more detailed and comprehensive than in public debt. Consistent with previous literature, the authors find a wide variation in the use of debt covenants through 23 countries. Specifically, they find an important use of these covenants on USA and Canada. But, a little use is found in countries like Greece and Japan. These countries use others tool to reduce agency cost of debt as indicated by Ball et al. [22]. To test the hypotheses of accounting conservatism and its relation with debt covenants, the authors made recourse to the model of Basu [4] to estimate timely loss recognition. In this model, they add a dummy variable that takes the value of 1 if there are debt covenants and 0 otherwise. This variable was introduced the only one in the model, than in interaction with every term of Basu [4] model such as stock return, dummy variable relative to negative stock return and the interaction with these last variables. In addition, they include control variables linked to firm characteristic that are likely to affect the conservatism demand as mentioned by Ahmed et al. [11]: size of the firm, market to book ratio, R\&D, PP\&E and dividends. Their result show that timely loss recognition increases with the use of debt covenants and this association is strong in the countries with strong enforcement. The results indicate also that timely loss recognition is higher for firms with a low market to book ratio, a high R\&D and with low PP\&E and having lower payment of dividend based on triple interaction term between firm characteristics, stock return and dummy variable relative to negative stock return. Globally, Hong et al. [21] are the first ones to examine the use of debt covenants under all the aspects through an international study. In the same order of idea, Nikolaev [6] examines if firms with more covenants in their public debt recognize timely loss. He focus on the role of timely loss recognition on public debt, and more specifically, on the direct link between debt covenants and the degree of accounting conservatism as mentioned by Guay and Verrecchia [10]. In the literature, there's two opposite views on how accounting conservatism is resolved in practice. The first view, suggests that timely loss recognition facilitates the early transfer of decisions rights from shareholders to bondholders as a firm approaches financial distress and thus reduces the probability of wealth expropriation [3], [9], [23]. In this case, without timely loss recognition, the efficiency of debt covenants in curbing agency cost of debt is lower, the accounting conservatism complements the debt covenants in reducing agency costs of debt The second view, maintains that while firms can meet the demand for accounting conservatism through adopting conservative accounting policies. In others term, firms can substitute the adoption of these policies to accounting numbers within a contract as indicated by Beatty and Weber [24]. In this case, timely loss recognition can substitute debt covenants. Using a sample of 3,000 public debt issues, firms with more covenants on their public debt are timelier in recognition losses as mentioned by Guay and Verrecchia [10]. In fact, firms with more restrictive contracts are twice conservative than firms with less restrictive debt contracts. The results are globally consistent with the view that the use of debt covenants increases the degree of accounting conservatism. The main criticism that we can signal to these studies that are all focused on Anglo-Saxon context.

The hypothesis to be verified within the framework of this paper relates to the impact of financial covenants presence in private debt contracts of French firms on accounting conservatism. In the light of previous study, we formulate our only hypothesis as follows:

H1: the accounting earnings of firms having financial covenants on their private debt recognize bad news timelier.

\section{The methodology and model}

The inclusion of financial covenants on private debt contracts represents a mechanism of solving conflicts between debtholders and managers. This study tries to see if the presence of financial covenants on debt contracts affects the quality of accounting earnings of French firms. In other terms, we seek to see if the presence of financial covenants on debt contracts enhance the degree of conservatism of accounting earnings by checking others determinants of accounting quality such as, the size of the firm, leverage, market to book, and the mandatory adoption of IAS/IFRS in 2005 by French firms which likely affect the accounting quality. This study offers the opportunity to observe the impact of financial covenants on the degree of conservatism, since, none study was led over this relation except an international study made by Hong et al. [21].

For that purpose, we use a sample of French firms over the period 2003-2009 for which we measure the accounting quality following the model of Basu [4].

\subsection{Measure of conservatism}

To test the presence of the effect of accounting conservatism, we use the more used measure empirically of accounting conservatism according to Ryan [8]. This is the measure of Basu[4] which appears as follows: 
$E_{i, t} / P_{i, t-1}=\beta_{0}+\beta_{1} D R_{i, t}+\beta_{2} R_{i, t}+\beta_{3} R_{i, t} * D R_{i, t+\varepsilon_{i, t}}$

$E_{i, t}$ : is earning per share

$P_{i, t-1}$ : is year end stock price per share

$R_{i, t}$ : is the buy and hold stock return over the fiscal year.

$D R_{i, t}$ : is a dummy variable that equals 1 if $\mathrm{R}$ is negative and 0 otherwise.

The coefficients on $\mathrm{R}\left(\beta_{2}\right)$ and $\mathrm{R} * \mathrm{D}\left(\beta_{3}\right)$ capture the reaction of earnings to contemporaneous "good news" and "bad news" respectively. Contextually, a positive $\beta_{3}$ is an indication of accounting conservatism. As a result, more this coefficient is important more the accounting conservatism is high.

\subsection{Measure of financial covenants}

Our interest variable is the presence of financial covenants on private debt of listed French firms. The financial covenant is binary variable that takes 1 if the private debt contract of a French firm has a financial covenants and zero otherwise.

\subsection{Measures of control variables}

Beside the interest variable (the presence of financial covenant on private debt contract) we add control variables that are linked to accounting conservatism. These variables will be among three respectively: the size, leverage and market to book. These variables were chosen because the conservatism varies with them empirically and theoretically as indicated by LaFond and Watts [25].

The market to book ratio: the market to book ratio is a proxy of the growth options. He affects negatively the asymmetry recognition of earnings as shown by Roychowdhury and Watts [26]. Firms with great options of opportunities are likely to demand great timely loss recognition. LaFond and Watts [25] suggest that more there are options of opportunities; the asymmetry of information will be higher between investors of funds of the firm. This ratio is calculated as market value of shares divided by her accounting value.

The size: firms with relatively high size are likely to be more mature and have a rich information environment reducing afterward the global uncertainty and information asymmetry related to the realization of future gains. Large firms have important transactions that can increase asymmetry information. Following Easley et al. [27], the mean of large firms have less asymmetry information than small firms. This suggests that the contracting demand of timely loss recognition will be weak for large firms. LaFond and Watts [25] indicate a negative relation between size of the firm and accounting conservatism since large firms are likely to have a weak information asymmetry. In the same vein, a negative relation between the size of the firm and accounting conservatism is found by LaFond and Roychowdhury [28]; the size of the firm is measured by the logarithm of total assets.

Leverage: leverage captures the demand of debt contracting for conservatism. Firms having higher leverage announce more conservative earnings as mentioned by Frankel and Roychowdhury [29]. This result is consistent with the existence of debt contracts based on accounting conservatism. In order to protect against wealth expropriations made in the detriment of debtholders, debt contract includes covenants formulated under accounting ratios to limit managerial actions. The hypotheses of Watts and Zimmerman [2] known under « debt hypotheses » according to which leveraged firms should to favor accounting methods that increase the current earnings. The conservatism turns out to be an effective tool in debt contracts next to covenants. It has interest to reduce these conflicts by trigger covenant violation in debt covenants [2, 30,3]. This suggests a contracting demand for conservatism for leveraged firms. This variable corresponds to the value of total debt divided by total assets.

These variables mentioned above are used in the literature of accounting conservatism. Indeed, another variable of control will be introduced in our study since our period of this study cover the going period 2003-2009 and during the year 2005, there was mandatory adoption of IAS/IFRS which are supposed to reduce or to increase accounting conservatism. We must thus take into account this variable.

Mandatory IAS/IFRS: the adoption of international standards driven by important changes on accounting methods in France and everywhere in different country who adopted these standards. These standards aim to enhance information relevance, reliability and comparability. The standard setters indicate that the adoption of IAS/IFRS reduces the information asymmetry, enhances comparability and reduces the cost of capital by supplying the lowest estimation of future cash flow and subsequently a more useful financial statement for investors. Many studies are made to examine the impact of these standards on accounting quality and the results are mixed. The evidence suggests an increase of earnings smoothing and a decrease on timely loss recognition in Germany as mentioned by Christensen and Walker [31]. The examination of 20 countries that adopted the IAS/IFRS and 15 that not adopted the IAS/IFRS, indicates a significant increase in the earnings smoothing, an increase on reporting aggressive of accruals and a decrease on timely loss recognition for firms that mandatory adopt the IAS/IFRS relative to the benchmark of firms that not adopt these standards as found by Ahmed et al. [32]. The increase of earnings smoothing, after the adoption of IAS/IFRS, was identified by countries like France and others as shown by Capkun et al. [33]. 
This variable is dummy and takes the value of 1 for the years 2005, 2006, 2007, 2008 and 2009 and the value of 0 for 2003 and 2004.

\section{The findings}

\subsection{Sample presentation}

Our study consists of 488 firm- year observations that are included in the index of SBF250; these firms are observed over the period of 2003 to 2009 . From the screening of firms, we eliminate firms whose belong to financial sector. We have also eliminated the outliers from the sample because it can bias the significance of the variables. So our sample is a panel, it is often interesting to identify the associated effect with every individual. This effect can be fixed or random. To settle between twice, the Hausman tests is the solution to determine if the coefficients of two estimations (fixed or random) are statistically different.

\subsection{Descriptive statistics}

Table 1: Descriptive Statistics

\begin{tabular}{lllll}
\hline variables & Mean & St Dev. & Min & Max \\
\hline \multicolumn{1}{c}{$E_{i, t} / P_{i, t-1}$} & 0,1205714 & 1.553274 & -15 & 26.66667 \\
$\mathrm{DR}$ & 0,3114754 & 0,4634421 & 0 & 1 \\
$\mathrm{R}$ & 0,1402521 & 1.23041 & $-8,125$ & 21,66667 \\
$\mathrm{DR} * \mathrm{R}$ & $-0,1297855$ & 0,2631348 & $-2,090494$ & 0,8384697 \\
\hline
\end{tabular}

The treatment of the variables by Stata11 software has revealed outliers. These outliers must be eliminated by a command in Stata11 because they bias the significance of variables. So, after elimination of outliers, descriptive statistics is as follow:

Table 2: Descriptive Statistics after Outliers Elimination

\begin{tabular}{lllll}
\hline variables & Mean & St Dev. & Min & Max \\
\hline \multicolumn{1}{c}{$E_{i, t} / P_{i, t-1}$} & 0,0554468 & 0,0715264 & $-0,2214286$ & 0,3258182 \\
$\mathrm{DR}$ & 0,3043478 & 0,4605016 & 0 & 1 \\
$\mathrm{R}$ & 0,0525121 & 0,4424733 & -1 & 1,604575 \\
$\mathrm{DR} * \mathrm{R}$ & $-0,1231202$ & 0,2488133 & -1 & 0,8384697 \\
\hline
\end{tabular}

The descriptive statistical analysis of our sample highlighted the following points:

We notice that the earnings by share of a French listed firm is about 5, 54\%. As regards, the negative stock return, it is equal on average to $30,4 \%$. It means that $30,4 \%$ of observations are classified as « bad news ».

Before starting the multivariate regression, it is necessary to pass by a correlation test of explicative variables since the linear regression require the absence of multicollinearity problem. To be made, we verify this condition by resorting to the test of spearman correlation between explicative variables. The table below shows results stemming from this test. The results show that there is not a problem of multicolinearity following Grobner et al. [34]. The test of VIF reveals also that there is not a problem of multicolinearity since VIF do not exceed the value of 5.

\begin{tabular}{llll} 
& \multicolumn{2}{c}{ Table 3 : Spearman Correlation } & DR*R \\
\hline $\mathrm{DR}$ & $\mathrm{DR}$ & $\mathrm{R}$ & \\
$\mathrm{R}$ & 1.0000 & & \\
& $-0.5559^{*}$ & 1.0000 & 1.0000 \\
$\mathrm{DR} * \mathrm{R}$ & 0.0000 & $0.5914^{*}$ & 0.0000 \\
\hline
\end{tabular}

Table 4: Vifs of Explicative Variables

\begin{tabular}{llll}
\hline & DR & $\mathrm{R}$ & $\mathrm{DR} * \mathrm{R}$ \\
\hline $\mathrm{VIFs}$ & 2.15 & 1.62 & 2.28 \\
\hline
\end{tabular}

\subsection{Empirical results}

The Basu model allows to capture the degree of conservatism.

Model 1:

$E_{i, t} / P_{i, t-1}=\beta_{0}+\beta_{1} D R_{i, t}+\beta_{2} R_{i, t}+\beta_{3} R_{i, t} * D R_{i, t}+\varepsilon_{i, t}$ 
$E_{i, t}:$ are earnings per share

$P_{i, t-1}$ : is year end stock price per share

$R_{i, t}:$ is the buy and hold stock return over the fiscal year.

$D R_{i, t}$ : is a dummy variable that equals 1 if $\mathrm{R}$ is negative and 0 otherwise.

The coefficients on $\mathrm{R}\left(\beta_{2}\right)$ and $\mathrm{R} * \mathrm{D}\left(\beta_{3}\right)$ capture the reaction of earnings to contemporaneous "good news" and "bad news" respectively. Contextually, a positive $\beta_{3}$ is an indication of accounting conservatism. As a result, more this coefficient is important; more the accounting conservatism is high.

\section{Model 1.1:}

$E_{i, t} / P_{i, t-1}=\beta_{0}+\beta_{1} D R_{i, t}+\beta_{2} R_{i, t}+\beta_{3} R_{i, t} * D R_{i, t}+\beta_{4}$ Fincov $+\beta_{5} D R_{i, t} *$ Fincov $+\beta_{6} R_{i, t} *$ Fincov $+\beta_{7} * D R_{i, t} *$ $R_{i, t} *$ Fincov $+\varepsilon_{i t}$

The interaction $R_{i, t} * D R_{i, t}$ gives an idea on the degree of association between negative stock return and accounting earnings. The interaction $D R_{i, t} * R_{i, t} *$ Fincov capture the impact of financial covenant presence on timely loss recognition.

The results of table 5 show that the model (1.1) is pooled. The variance of independent variables of Basu [4] model explain 7, 24\% of earnings per share variance for listed French firms. The introduction of fincov variable in the model of Basu [4] and his interaction with the others variables of the model lead to a light improvement of the percentage of earnings per share variance explained by dependant variables of the model which passes from $7,24 \%$ to $8,81 \%$.

The coefficient $\beta_{7}$ relative to the interaction $D R_{i, t} * R_{i, t} *$ Fincov over the period of 7 years is positive and significant at the level of $5 \%$. This confirms the first hypotheses according to which accounting conservatism increases in the presence of financial covenants in private debt contracts of French listed firms. This confirms the result of [6, 21], stipulating that accounting conservatism increase the relevance of debt covenants. In addition, the accounting conservatism increases the presence of financial covenants in the private debt contracts; this result signals that the timely loss recognition and the presence of financial covenants are two complement mechanism following Nikolaev [6].

Table 5: Impact of Financial Covenants on Timely Loss Recognition Following Basu [4]

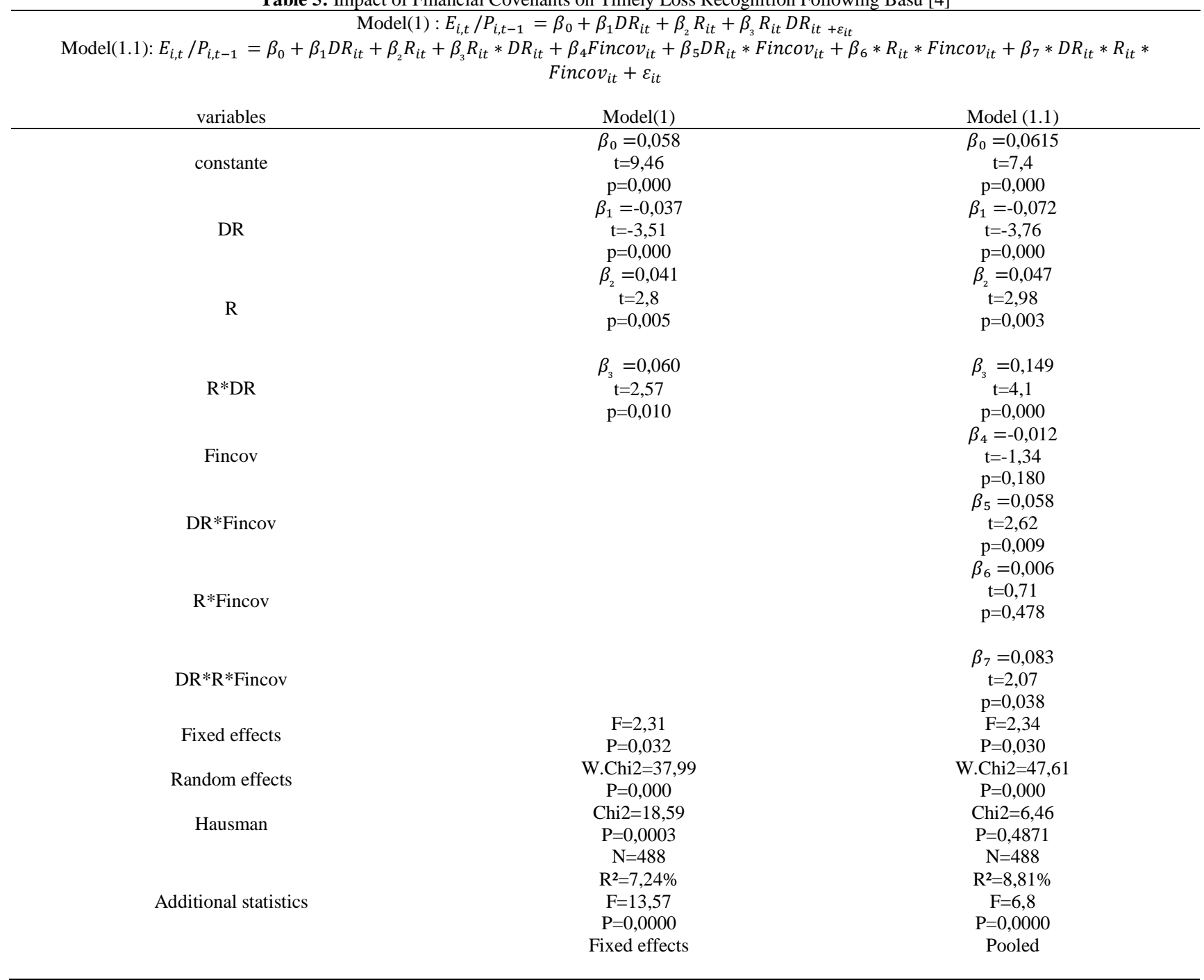


Variables definition: : $\mathbf{E}_{\mathbf{i}, \mathbf{t}} / \mathbf{P}_{\mathbf{i}, \mathbf{t}-\mathbf{1}}$ : earnings per share divided by year end stock price per share. $\mathbf{D R}_{\mathbf{i t}}$ : Dummy variable that takes the value of 1 if stock return is negative and 0 otherwise. $\mathbf{R}_{\mathbf{i t}}$ : Stock returns of firm $\mathrm{i}$ under the period $\mathrm{t}$. Fincov $_{\text {it }}$ : dummy variable that takes the value of 1 if there's a financial covenant on debt contract of firm $i$ and 0 otherwise. WChi 2: Wald chi-deux statistic.

Moreover, the result indicates that the coefficient on $\beta_{7}$ relative to the triple interaction $\mathrm{R} * \mathrm{DR} *$ Fincov is 0,083 . The coefficient $\beta_{3}$ of double interaction $\mathrm{DR} * \mathrm{R}$ is 0,149 represent the basis of the degree of conservatism with no financial covenant. This result suggests that the adjunction of financial covenant on private debt corresponds to the increase of $55,7 \%$ ( equal $0,083 / 0,149$ ) in the degree of conservatism. So our results are economically significant.

To better understand the impact of the presence financial covenants on the degree of accounting conservatism, we introduce some control variables that are likely to influence accounting conservatism. These control variables are IFRS that take the value of 1 for the years 2005-2009 and 0 for the years 2003-2004, leverage that corresponds to long term debt divided by total assets, market to book ratio is the market value of share divided by its accounting value and finally size of the firm which is the logarithm of total assets;

To test, thus, the impact of these control variables on timely loss recognition, we add them one by one in the regression model in interaction with others terms of Basu [4] model. The model that include fincov and others control variables is as follow:

\section{Model 1.2:}

$R P A_{i t}=\beta_{0}+\beta_{1} D R_{i t}+\beta_{2} R_{i t}+\beta_{3} R_{i t} * D R_{i t}+\beta_{4} F_{i n c o v}+\beta_{5} D R_{i t} * F_{i n c o v}+\beta_{6} R_{i t} * F_{i n c o v}+\beta_{7} D R_{i t} * R_{i t} *$ Fincov $_{i t}+\beta_{8} I F R S_{i t}+\beta_{9} D R_{i t} * I F R S_{i t}+\beta_{10} R_{i t} * I F R S_{i t}+\beta_{11} R_{i t} * D R_{i t} * I F R S_{i t}+\beta_{12}$ leverage $_{i t}+\beta_{13} D R_{i t} *$ leverage $_{i t}+\beta_{14} R_{i t} *$ leverage $_{i t}+\beta_{15} R_{i t} * D R_{i t} *$ leverage $_{i t}+\beta_{16} M T B_{i t}+\beta_{17} D R_{i t} * M T B_{i t}+\beta_{18} R_{i t} * M T B_{i t}+$ $\beta_{19} R_{i t} * D R_{i t} * M T B_{i t}+\beta_{20}$ Size $_{i t}+\beta_{21} D R_{i t} * \operatorname{Size}_{i t}+\beta_{22} R_{i t} * \operatorname{Size}_{i t}+\beta_{23} R_{i t} * D R_{i t} * \operatorname{Size}_{i t}+\varepsilon_{i t}$

The results of this model are included in table 6 . Before analyzing the impact of these different control variables on timely loss recognition, we signal that the impact of financial covenants presence on debt private contract of French listed firms through the coefficient $\beta_{7}$ is positive and significant whatever the control variable kept.

The results of model (1.2) highlight that the taking into account of IFRS control variable is not beneficial for the understanding of the evolution of timely loss recognition since the coefficient associated with this variable namely $\beta_{11}$ is negative and no significant whatever the control variable kept. This result indicates that the passage in 2005 to IFRS do not seem to have a significant effect on accounting conservatism.

As regards the adding of control variables namely: leverage, market to book and size of the firm, we add only these variables because they are the commonly determinants of accounting conservatism in the literature [35, 28]. The results show that these variables have no effect on accounting conservatism. These results are not consistent with the literature. Indeed, Hong et al. [21] signal in their international study that timely loss recognition is higher for firms with a low market to book and tangibility and a high R\&D.

$R P A_{i t}=\beta_{0}+\beta_{1} D R_{i t}+\beta_{2} R_{i t}+\beta_{3} R_{i t} * D R_{i t}+\beta_{4} F_{i n c o v}+\beta_{5} D R_{i t} * F_{i n c o v} i t+\beta_{6} R_{i t} * F_{i n c o v}+\beta_{7} D R_{i t} * R_{i t} *$ Fincov $_{i t}+\beta_{8} I F R S_{i t}+\beta_{9} D R_{i t} * I F R S_{i t}+\beta_{10} R_{i t} * I F R S_{i t}+\beta_{11} R_{i t} * D R_{i t} * I F R S_{i t}+\beta_{12}$ leverage $_{i t}+\beta_{13} D R_{i t} *$ leverage $_{i t}+\beta_{14} R_{i t} *$ leverage $_{i t}+\beta_{15} R_{i t} * D R_{i t} *$ leverage $_{i t}+\beta_{16} M T B_{i t}+\beta_{17} D R_{i t} * M T B_{i t}+\beta_{18} R_{i t} * M T B_{i t}+$ $\beta_{19} R_{i t} * D R_{i t} * M T B_{i t}+\beta_{20}$ Size $_{i t}+\beta_{21} D R_{i t} * \operatorname{Size}_{i t}+\beta_{22} R_{i t} * \operatorname{Size}_{i t}+\beta_{23} R_{i t} * D R_{i t} * \operatorname{Size}_{i t}+\varepsilon_{i t}$

Table 6: Others Determinants of Timely Loss Recognition Model 1.2

\begin{tabular}{|c|c|c|c|c|}
\hline Variables & Model (1.2.1a) & Model (1.2.1b) & Model (1.2.1c) & Model (1.2.1d) \\
\hline constante & $\begin{array}{l}\beta_{0}=0,050 \\
\mathrm{t}=5,38 \\
\mathrm{p}=0,000\end{array}$ & $\begin{array}{l}\beta_{0}=0,042 \\
\mathrm{t}=3,76 \\
\mathrm{p}=0,000\end{array}$ & $\begin{array}{l}\beta_{0}=0,052 \\
\mathrm{t}=4,36 \\
\mathrm{p}=0,000\end{array}$ & $\begin{array}{l}\beta_{0}=0,038 \\
\mathrm{t}=1,09 \\
\mathrm{p}=0,275\end{array}$ \\
\hline DR & $\begin{array}{l}\beta_{1}=-0,052 \\
\mathrm{t}=-1,87 \\
\mathrm{p}=0,062\end{array}$ & $\begin{array}{l}\beta_{1}=-0,049 \\
\mathrm{t}=-1,51 \\
\mathrm{p}=0,125\end{array}$ & $\begin{array}{l}\beta_{1}=-0,044 \\
\mathrm{t}=-1,49 \\
\mathrm{p}=0,138\end{array}$ & $\begin{array}{l}\beta_{1}=0,039 \\
\mathrm{t}=0,46 \\
\mathrm{p}=0,648\end{array}$ \\
\hline $\mathrm{R}$ & $\begin{array}{l}\beta_{2}=0,057 \\
\mathrm{t}=3,55 \\
\mathrm{p}=0,000\end{array}$ & $\begin{array}{l}\beta_{2}=0,065 \\
t=3,24 \\
p=0,001\end{array}$ & $\begin{array}{l}\beta_{2}=0,042 \\
\mathrm{t}=2,14 \\
\mathrm{p}=0,033\end{array}$ & $\begin{array}{l}\beta_{2}=0,049 \\
\mathrm{t}=2,86 \\
\mathrm{p}=0,004\end{array}$ \\
\hline $\mathrm{R} * \mathrm{DR}$ & $\begin{array}{l}\quad \beta_{3}=0,143 \\
\mathrm{t}=2,47 \\
\mathrm{p}=0,014\end{array}$ & $\begin{array}{l}\beta_{3}=0,150 \\
\mathrm{t}=2,39 \\
\mathrm{p}=0,017\end{array}$ & $\begin{array}{l}\beta_{3}=0,107 \\
\mathrm{t}=1,79 \\
\mathrm{p}=0,074\end{array}$ & $\begin{array}{l}\beta_{3}=0,029 \\
\mathrm{t}=0,18 \\
\mathrm{p}=0,857\end{array}$ \\
\hline Fincov & $\begin{array}{l}\beta_{4}=0,004 \\
\mathrm{t}=0,39 \\
\mathrm{p}=0,669\end{array}$ & $\begin{array}{l}\quad \beta_{4}=0,007 \\
\mathrm{t}=0,58 \\
\mathrm{p}=0,563\end{array}$ & $\begin{array}{l}\beta_{4}=0,001 \\
\mathrm{t}=0,12 \\
\mathrm{p}=0,908\end{array}$ & $\begin{array}{l}\beta_{4}=0,006 \\
\mathrm{t}=0,58 \\
\mathrm{p}=0,561\end{array}$ \\
\hline DR*Fincov & $\begin{array}{l}\beta_{5}=0,0422 \\
\mathrm{t}=1,83 \\
\mathrm{p}=0,068\end{array}$ & $\begin{array}{l}\beta_{5}=0,042 \\
\mathrm{t}=1,73 \\
\mathrm{p}=0,084\end{array}$ & $\begin{array}{l}\beta_{5}=0,048 \\
\mathrm{t}=2,05 \\
\mathrm{p}=0,041\end{array}$ & $\begin{array}{l}\beta_{5}=0,049 \\
\mathrm{t}=2,00 \\
\mathrm{p}=0,046\end{array}$ \\
\hline R*Fincov & $\begin{array}{l}\beta_{6}=-0,047 \\
\mathrm{t}=-2,16 \\
\mathrm{p}=0,032\end{array}$ & $\begin{array}{l}\beta_{6}=-0,049 \\
t=-1,62 \\
p=0,105\end{array}$ & $\begin{array}{l}\beta_{6}=-0,045 \\
\mathrm{t}=-1,93 \\
\mathrm{p}=0,055\end{array}$ & $\begin{array}{l}\beta_{6}=-0,059 \\
\mathrm{t}=-2,57 \\
\mathrm{p}=0,011\end{array}$ \\
\hline $\mathrm{R} * \mathrm{DR} *$ Fincov & $\begin{array}{l}\beta_{7}=0,134 \\
\mathrm{t}=2,93\end{array}$ & $\begin{array}{l}\beta_{7}=0,145 \\
\mathrm{t}=2,81\end{array}$ & $\begin{array}{l}\beta_{7}=0,146 \\
\mathrm{t}=3,08\end{array}$ & $\begin{array}{l}\beta_{7}=0,162 \\
\mathrm{t}=3,39\end{array}$ \\
\hline
\end{tabular}




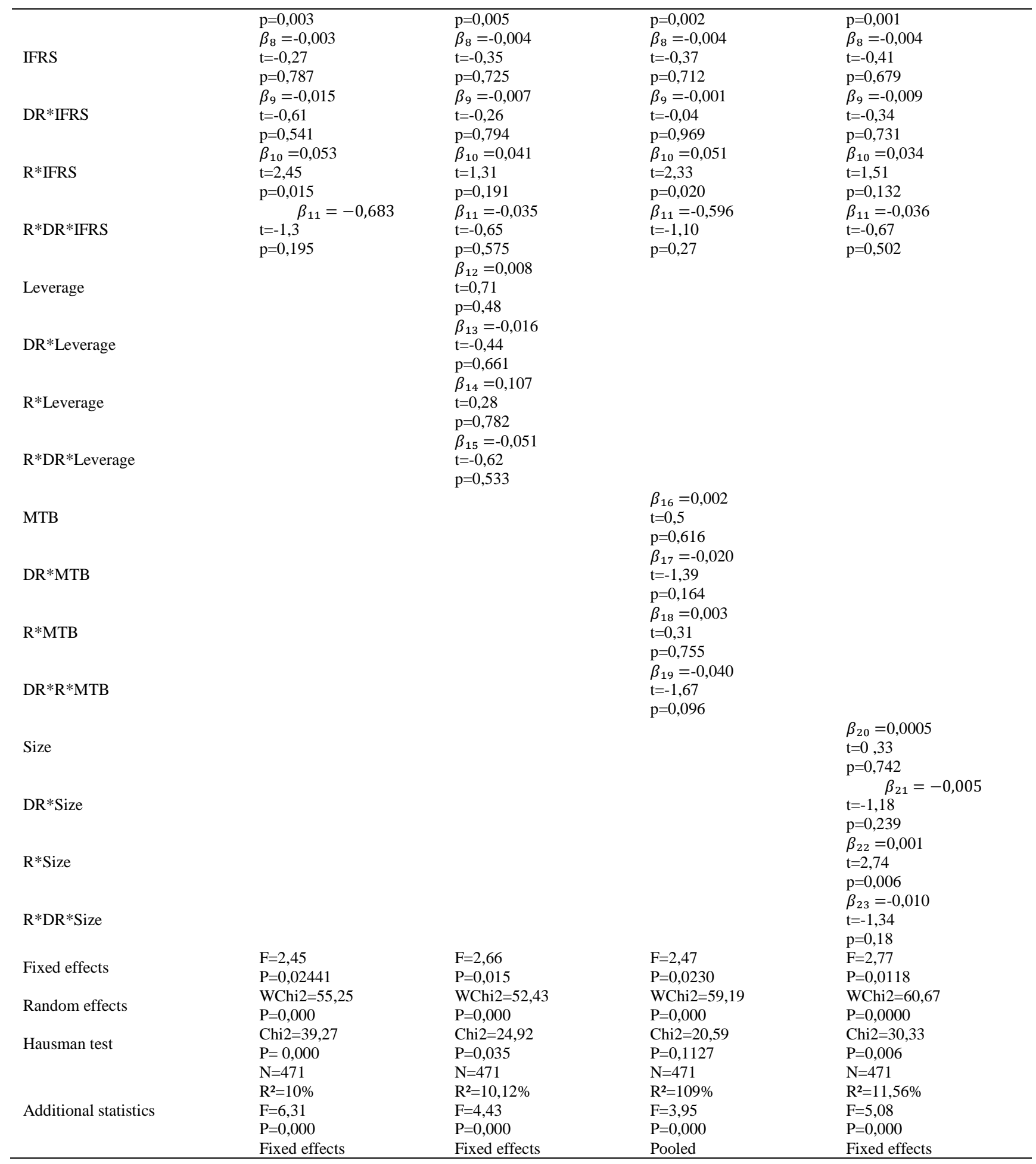

Definition of variables : $\mathbf{E}_{\mathbf{i}, \mathbf{t}} / \mathbf{P}_{\mathbf{i}, \mathbf{t}-\mathbf{1}}$ : earnings per share divided by year end stock price per share. $\mathbf{D R}_{\mathbf{i t}}$ : Dummy variable that takes the value of 1 if stock return is negative and 0 otherwise. $\mathbf{R}_{\mathbf{i t}}$ : Stock returns of firm $\mathrm{i}$ under the period $\mathrm{t}$. Fincov $_{i t}$ : dummy variable that takes the value of 1 if there's a financial covenant on debt contract of firm $i$ and 0 otherwise. leverage $\mathbf{i t}_{\mathbf{i t}}$ : Is total debt divided by total assets. $\mathbf{M T B}_{\mathbf{i t}}$ : is market value of shares divided by accounting value of shares. Size $\mathbf{i t}_{\mathbf{i t}}$ : is the logarithm of total assets. IFRS $_{\mathbf{i t}}$ : This variable is dummy and takes the value of 1 for the years 2005, 2006, 2007, 2008 and 2009 and the value of 0 for 2003 and 2004. WChi 2: Wald chi-deux statistic

\section{Summary and conclusions}

In this paper, we tried to put in relation the accounting conservatism and the presence of financial covenants included on private debt contracts. In fact, the accounting conservatism principle requires timely loss recognition became an important mechanism for debtholders next to the presence of financial covenants in the reduction of agency cost debt. 
To examine the effect of conditional conservatism, we adopted the measure of Basu [4] which put the relation accounting earnings with stock return. So, we examined the relation between the presence of financial covenants and timely loss recognition. The results show that there is a positive relation between the financial covenants and accounting conservatism. We can notice that firms with financial covenants in their debt contracts recognize timelier bad news. Consequently, financial covenants and accounting conservatism are complements in the French context. Afterward, we integrated control variables such as leverage, market to book ratio and size of the firm. We also integrated the control variable IAS/IFRS since the studied period include the year 2005 from which there was come into effect new standards IAS/IFRS. In fact, the results signal that no control variable is significant. The results of this study contributed certainly to the understanding of the relation between financial covenants and accounting conservatism in the French context. However, it is sufficient to talk about complementarity between the presence of financial covenants on debt contracts and timely loss recognition using a single measure?

\section{References}

[1] C. Smith, J. Warner, On financial contracting: An analysis of bond covenants, Journal of Financial Economics 7 (1979): $117-161$.

[2] R. Watts, J. Zimmerman, Positive Accounting Theory, New Jersey: Prentice-Hall Inc. Englewood Cliffs, 1986.

[3] R.L. Watts, Conservatism in Accounting, Part1: explanations and implications, Accounting Horizons 17(2003a) 207-221.

[4] S.Basu, The conservatism principle and the asymmetric timeliness of earnings, Journal of Accounting Economics 24 (1997) 3-37.

[5] J. Zhang, The contracting benefits of accounting conservatism to lenders and borrowers, Journal of Accounting Economics 45 (2008) $27-54$.

[6] V.V. Nikolaev, Debt Covenants and Accounting Conservatism, Journal of Accounting Research 48(2010) 137-176.

[7] H. Chen, Q.Tang, Y.Yiang, Z. Lin, The role of international financial reporting standards in accounting quality: Evidence from the European Union, Journal of International Financial. Management and Accounting 21(2010) 220-278.

[8] S. Ryan, Identifying conditional conservatism, European Accounting Review 4 (2006) 511-525.

[9] R. Ball, L.Shivakumar, Earnings quality in UK private firms: comparative loss recognition timeliness, Journal of Accounting and Economics 34 (2005) 83-128.

[10] W. Guay, R. Verrechia, Discussion of an economic framework for conservative accounting, Journal of Accounting and Economics 42 (2006)149-165

[11] A.S. Ahmed, B. Billings, M.S. Harris, R.M. Morton, The Role of Accounting Conservatism in Mitigating Bondholders-Shareholders Conflicts over Dividend Policy and in Reducing Debt Cost, Accounting Review 77 (2002) 867-890.

[12] R. Wittenberg-Moerman, The role of information asymmetry and financial reporting quality in debt contracting: Evidence from the secondary loan market, Journal of Accounting and Economics 46 (2008) 240-260

[13] F. Vasvari, Managerial incentives structures, conservatism and the pricing of syndicated loans, Working Paper (2006).

[14] R.M. Frankel, L.P.Litov, Financial Accounting Characteristics and debt covenants.(2007) Available online: http://www.ssrn.com/abstract=978711.

[15] J.Begley, S. Chamberlain, The use of debt covenants in public debt agreements: An empirical investigation.Working Paper. University of British Columbia2009.

[16] E. Gutierrez, Evidence on the role of accounting conservatism in debt contracting. Working Paper. University of California, Los Angeles 2011.

[17] M. Jensen, W. Meckling, Theory of the firm: Managerial behavior, agency costs and ownership structure, Journal of Financial Economics 3 (1976) 305-360

[18] R.C.Nash, J.M. Netter, A.B. Poulsen, Determinants of contractual relations between shareholders and bondholders: investment opportunities and restrictive covenants, Journal of Corporate Finance 9 (2003)201-232.

[19] J. Begley, Restrictive covenants included in public debt agreements: An empirical investigation. Working Paper. University of British Columbia1994.

[20] C. Levine, J. Hughes, Management compensation and earnings based covenants as signaling devices in credit markets, Journal of Corporate Finance 11(2005) 832- 850.

[21] H.A. Hong, M. Hung, J. Zhang, The use of debt covenants worldwide: institutional Determinants and implications on financial reporting2011. Available online: http://www.ssrn.com/abstract:1496611

[22] R. Ball, S.P Kothari, A. Robin, The effect of international institutional factors on properties of accounting earnings. Journal of Accounting Economics 29 (2000) 1-51.

[23] R. Ball, A. Robin, G. Sadka, Is Accounting Conservatism Due to Debt or Equity Markets? An International Test of "Contracting" and "Value Relevance" Theories of Accounting. Working paper series 2005.

[24] A. Beatty, J. Weber, J.J. Yu, Conservatism and Debt, Journal of Accounting and Economics, 45 (2008) $154-174$.

[25] R. LaFond, R.L. Watts, The information role of conservative financial statements. The Accounting Review 83 (2008) 447-478.

[26] S.Roychowdhury, R.L. Watts, Asymmetric timeliness of earnings, market to book and conservatism in financial reporting, Journal of Accounting and Economics 44 (2007) 2- 31.

[27] D. Easley, S. Hvidkjaer, M. O’Harra, Is information risk a determinant of asset returns, Journal of Finance 57 (2002) $2185-2221$.

[28] R. LaFond, S. Roychowdhury, Managerial ownership and accounting conservatism, Journal of Accounting Research 46 (2008) $101-135$.

[29] R.M. Frankel, S. Roychowdhury, Testing the clientele effect: an explanation for non GAAP earnings adjustements used to compute I/B/E/S earnings. Working Paper, 2005, MIT.

[30] R. Watts, A proposal for research on conservatism. Working paper 1993.

[31] H. Christensen, E. Lee, M. Walker, Incentives or Standards: what determines accounting quality changes around IFRS adoption? Working Paper. 2008 University of Minnesota.

[32] A.S. Ahmed, M. Neel, D. Wang, Does Mandatory adoption of IFRS improves Accounting quality? Preliminary evidence. Working Paper. 2012 Texas A\&M University and University of Houston.

[33] V. Capkun, A.J. Cazavan, T. Jeanjean, L.A. Weiss,. Earnings management and value relevance during the mandatory transition from local GAAPs to IFRS in Europe. Working Paper. (2008), Avaialable on line: http://ssrn.com/abstract:1125716.

[34] D.F. Groebner, P.W. Shannon., P.C. Fry, K.D. Smith, Business statistics: a decision- making approach (7ème edition, Pertinence Hall). New Jersey, 2008; 696

[35] M. Khan, R.L. Watts, Estimation and empirical properties of a firm- year measure of accounting conservatism. Journal of Accounting and Economics 48 (2009) 132-150. 